\title{
Estimated changes of drought tendency in the Carpathian Basin
}

\author{
Judit SÁBITZ, Rita PONGRÁCZ and Judit BARTHOLY ${ }^{1}$
}

\begin{abstract}
Drought conditions are often characterized by various drought indices. In this paper different types of indices (i.e. standardized precipitation anomaly index, THORNTHWAITE's aridity index, and PED's drought index) are used to estimate the future changes in drought conditions in the Carpathian Basin. For this purpose $25 \mathrm{~km}$ horizontal resolution gridded outputs of several regional climate models are used from the project ENSEMBLES covering the period 1951-2100 and taking into account the A1B emissions scenario. The results suggest remarkable drying in the region, especially, in summer, which emphasize the importance of developing appropriate adaptation strategies addressing this issue.
\end{abstract}

Keywords: drought index, ENSEMBLES, regional climate model simulation, climate change

\section{Introduction}

Climatic conditions evidently affect the biosphere as well as the human societies. Anthropogenic activity influences the biosphere through land use change and agriculture (e.g. cultivating selected crops and thus decreasing biodiversity) for several centuries. Moreover, the 250 year long industrial activities (especially, fossil fuel combustion) resulted in increasing atmospheric concentration of greenhouse gases. As a consequence, global and regional warming has been detected (IPCC, 2013), which intensified drought conditions in many regions including Central and Southern Europe (IPCC, 2012). Hungary is certainly affected by this potential risk since it is located in the continental Central European zone. In the recent years, the entire continent was hit by a severe drought event in 2003, which included Hungary as well, as the whole Carpathian Basin (Tallaksen, L.M. et al. 2011). On the basis of

\footnotetext{
${ }^{1}$ Department of Meteorology, Eötvös Loránd University, Budapest 1117 Hungary. E-mails: sabitzj@nimbus.elte.hu, prita@nimbus.elte.hu, bartholy@caesar.elte.hu
} 
the measurement recorded by the Hungarian Meteorological Service the annual precipitation of the country was only 75 percent of the climatic mean (for the period 1971-2000). In 2011 the annual precipitation in Hungary was even smaller, only 72 percent of the normal value. Parts of the country were affected by drought events in 2002, 2007 and 2012.

Due to the recent increasing frequency of unusual years, it is essential to assess the possible future conditions in the country using regional climate model (RCM) simulations. These tools are widely used to estimate the primary climatic conditions, i.e. temperature and precipitation. Projected changes are summarized for Hungary in Pongrácz, R. et al. (2011), according to which regional warming is very likely to continue and increase in this century. Projected precipitation changes are varying throughout the year. RCMs clearly estimate summer drying for this century, however, in the other seasons different RCMs estimate different tendencies both in intensity and sign. Drought conditions are not determined only by precipitation conditions but also by temperature changes, this bivariate dependence can be assessed by drought indices.

In this paper first, the different types of drought indices are summarized and the three indices used in this paper are presented in details. Then, data outputs of RCM simulations available from project ENSEMBLES are described, followed by the discussion of the results. Finally, the conclusions are drawn.

\section{Drought indices}

Several aspects of the climatic system are directly or indirectly affected by precipitation deficiency, i.e. drought events. Therefore different scientific communities use different approaches to define drought itself and measures to characterize it. For instance, atmospheric science defines meteorological drought as a long period of time with considerably less precipitation amount than climatic mean. Other aspects may highlight the agricultural consequences, and define agricultural drought when the soil moisture is inadequate, and yields are considerably less than average because of the water shortage. Furthermore, hydrological drought refers to a period of below normal stream-flow, thus, focusing on the hydrological impacts of the lack of precipitation, such as reduced groundwater levels. Finally, economic drought considers the monetary value of drought-related damages, which can happen when the water shortage has an effect on human activity and on economy.

One of the most often used measures of drought includes the definition of several drought indices, which are able to quantify the temporal and spatial range of dry periods. The can be classified into different categories. Typically, there are four main groups of indices, which are widely used: the precipitation, the water balance, the recursive and the soil moisture indices 
(FARAGó, T. et al. 1988). Table 1 summarizes the traditional classification of drought indices, whereas Table 2 lists most of the well-known drought indices according to DunKel, Z. (2009).

Table 1. Classification of drought indices

\begin{tabular}{c|l}
\hline \multicolumn{1}{c|}{ Index types } & \multicolumn{1}{c}{ Examples } \\
\hline Precipitation indices & $\begin{array}{l}\text { Relative anomaly index } \\
\text { Standardized precipitation anomaly index } \\
\text { Relative precipitation anomaly index } \\
\text { Precipitation anomaly index }\end{array}$ \\
\hline \multirow{2}{*}{ Water balance indices } & $\begin{array}{l}\text { Lang's rainfall index } \\
\text { De Martonne aridity index } \\
\text { Thornthwaite index }\end{array}$ \\
\hline Recursive indices & $\begin{array}{l}\text { Foley's anomaly index } \\
\text { Palmer's drought index }\end{array}$ \\
\hline Soil moisture indices & $\begin{array}{l}\text { Ped's drought index } \\
\text { Relative soil moisture index }\end{array}$ \\
\hline Remotely sensed indices & $\begin{array}{l}\text { Vegetation index } \\
\text { Normalized difference vegetation index }\end{array}$ \\
\hline
\end{tabular}

Precipitation indices are suitable for the separation of wet and dry periods, as well as for the determination of variability. They are simple and do not require large datasets. Water balance indices are more complex. In addition to precipitation they also take into account temperature, which is used as the main factor of evaporation from the output side of the water balance. Recursive indices consider cumulative effects of precipitation shortage since they use data from the preceding period and hence characterize longer time periods. Soil moisture indices are able to estimate crop loss and agricultural water shortage. The main advantage of the indices based on remotely sensed information is the good spatial coverage for large areas.

In order to keep a reasonable length of this paper, standardized precipitation anomaly index (SAI), PED's drought index (PDI) and ThornthwaIte's aridity index (TAI) are used to estimate the projected trends of dry climatic conditions by the end of the $21^{\text {st }}$ century in the Carpathian Basin (ThornthwaIte, C.W. 1948; Ped, D.A. 1975).

One of the most simple indices is SAI (Katz, R.W. and Glantz, M.H. 1986). The main advantage of this dimensionless index that it can be calculated only from precipitation time series. In addition, $S A I$ is a standardized measure for seasonal differences and for precipitation in different climatic areas. Based on the definition the negative/positive trend of $S A I$ implies drier/wetter climatic conditions. The drought classification using SAI values is shown in Table 3.

TAI is widely used in agrometeorological studies (THORNTHWAITE, C.W. 1948). For calculating TAI temperature time series are also used in ad- 


\begin{tabular}{|c|c|c|c|c|c|c|c|}
\hline 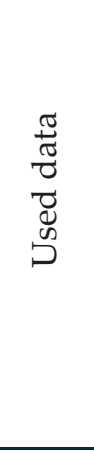 & 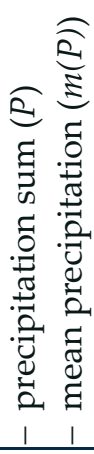 & 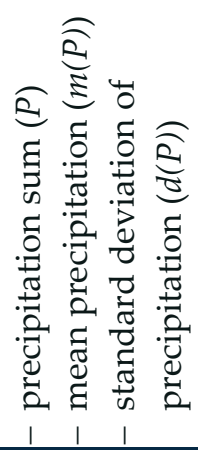 & 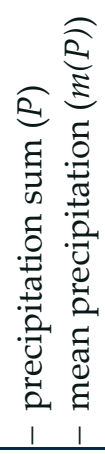 & 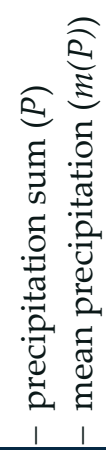 & 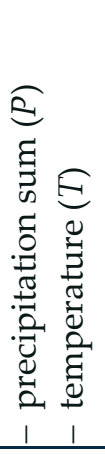 & 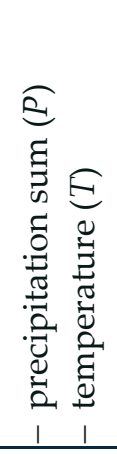 & 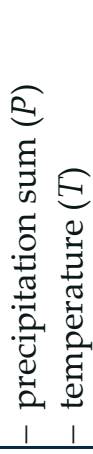 \\
\hline 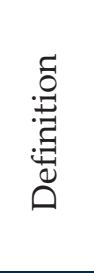 & $\overbrace{\substack{E \\
1 \\
2}}^{\overparen{2}}$ & 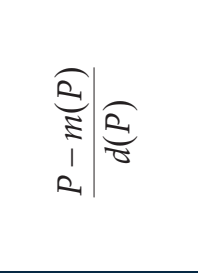 & 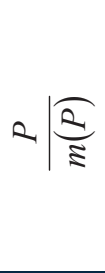 & 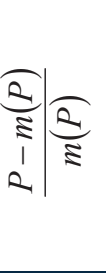 & \begin{tabular}{l|l}
0 & 0 \\
$\dot{\sim}$ & + \\
$\sim$ & +
\end{tabular} & 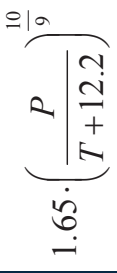 & $R \mid K$ \\
\hline 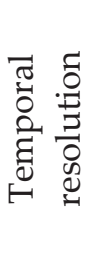 & 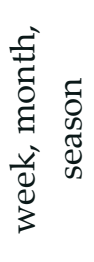 & 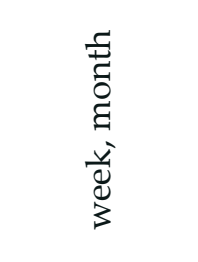 & 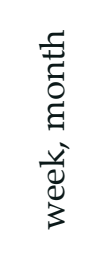 & 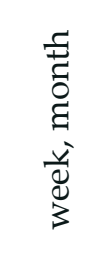 & 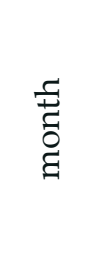 & 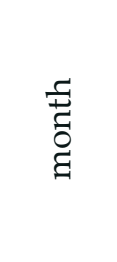 & 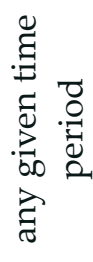 \\
\hline 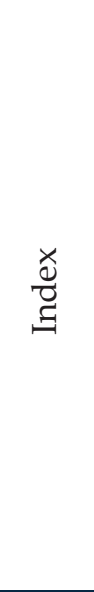 & 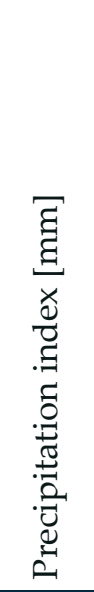 & 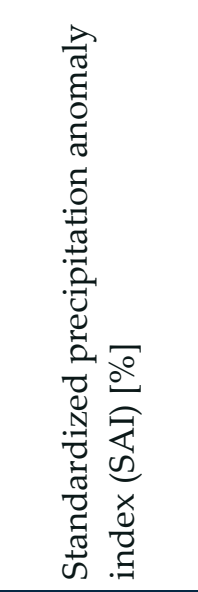 & 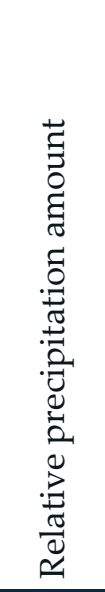 & 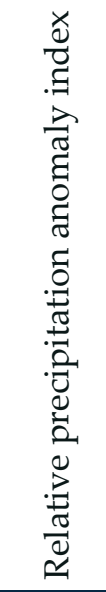 & 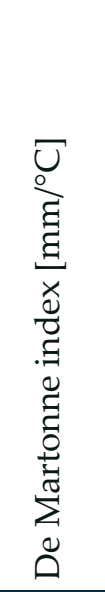 & 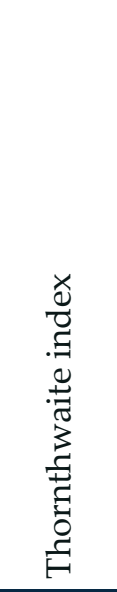 & 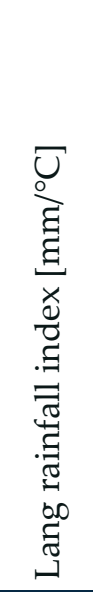 \\
\hline$\dot{\mathrm{Z}}$ & $\dot{-}$ & i & $\dot{\theta}$ & $\dot{+}$ & 10 & 6 & $\Lambda^{\circ}$ \\
\hline
\end{tabular}




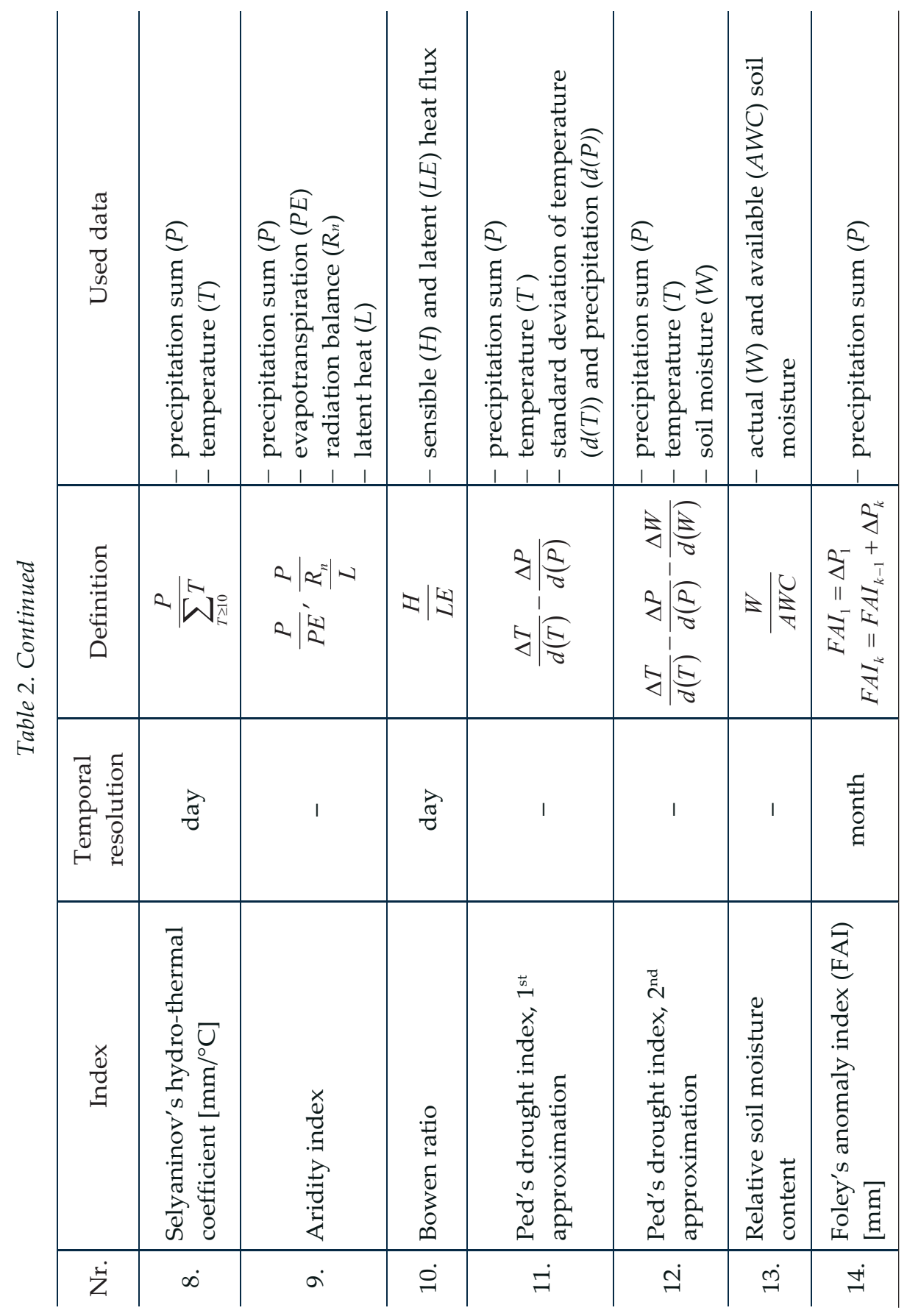




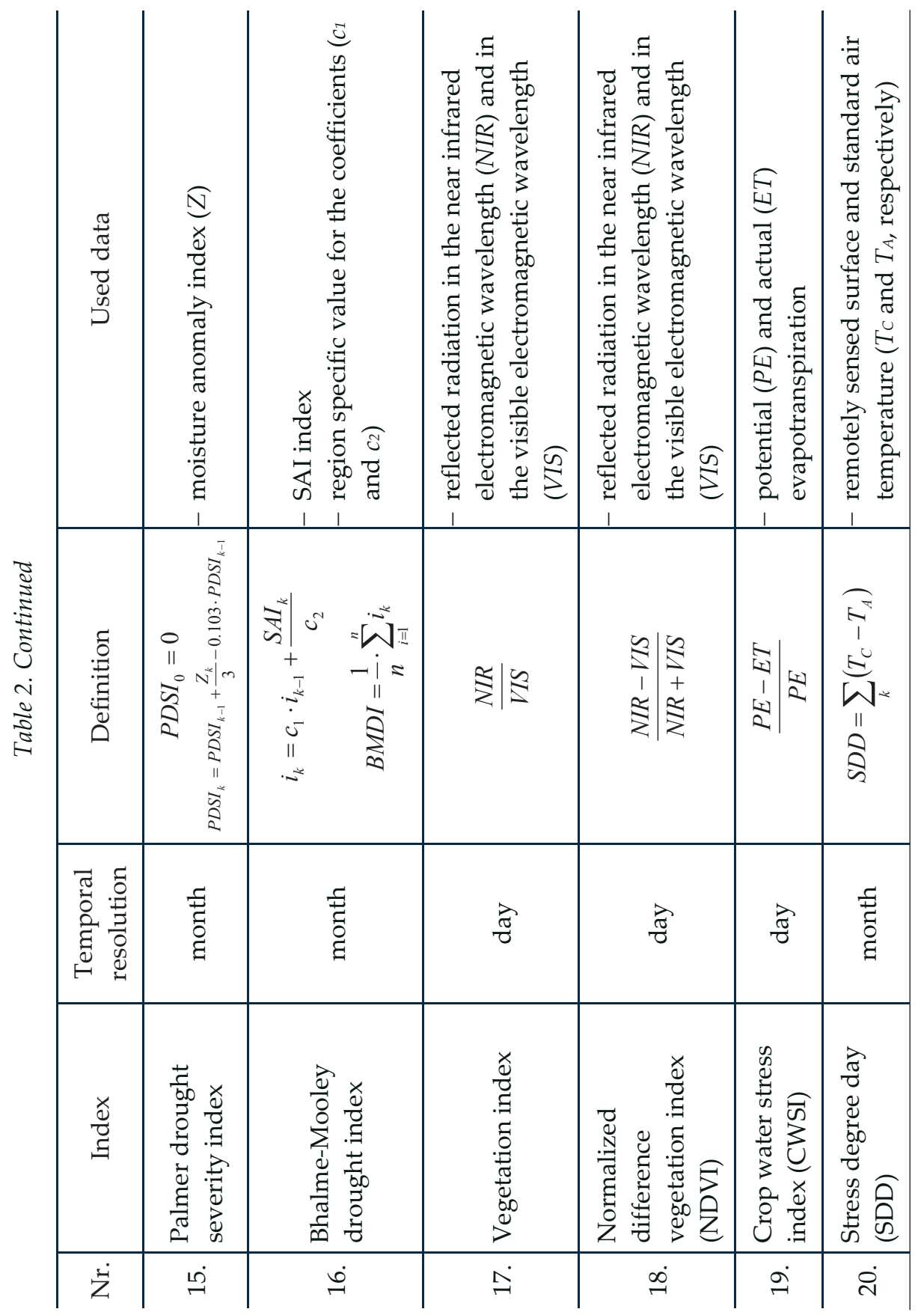


Table 3. Drought categories defined on the basis of SAI values

\begin{tabular}{c|l}
\hline \multicolumn{1}{c|}{ SAI values } & \multicolumn{1}{c}{ Category } \\
\hline$>2.0$ & extremely wet \\
1.5 to 2.0 & severely wet \\
1.0 to 1.5 & moderately wet \\
-1.0 to +1.0 & near normal \\
-1.0 to -1.5 & moderately dry \\
-1.5 to -2.0 & severely dry \\
$<-2.0$ & extremely dry \\
\hline
\end{tabular}

Table 4. Drought categories defined on the basis of TAI values

\begin{tabular}{c|l}
\hline \multicolumn{1}{c|}{ TAI values } & \multicolumn{1}{|c}{ Category } \\
\hline$>6.4$ & wet \\
3.2 to 6.4 & semi-arid \\
1.6 to 3.2 & arid \\
$<1.6$ & extremely dry \\
\hline
\end{tabular}

Table 5. Drought categories defined on the basis of PDI values

\begin{tabular}{c|l}
\hline \multicolumn{1}{c|}{ PDI values } & \multicolumn{1}{c}{ Category } \\
\hline$<-3$ & extremely wet \\
-3 to -2 & severely wet \\
-2 to -1 & moderately wet \\
1 to 2 & moderately dry \\
2 to 3 & severely dry \\
$>3$ & extremely dry \\
\hline
\end{tabular}

dition to precipitation (KЕMP, D. 1990). Decreasing/increasing trend of TAI means drier/wetter climatic conditions. Table 4 shows the different drought categories according to TAI.

For complex studies it can be useful to compare standardized values of temperature and precipitation in order to obtain a more accurate result. PDI (Bagrov, N.A. 1983; Ped, D.A. 1975) is a soil moisture index, which trends are opposite to SAI or TAI, namely, decreasing/ increasing trend indicates wetter/drier conditions. PDI values close to zero (between -1 and +1) implies neutral states. Drought classification using PDI values is shown in Table 5.

\section{Data}

To assess uncertainty due to natural and anthropogenic forcing factors, future climatic conditions are estimated with an ensemble of climate models. For Europe the five-year-long project ENSEMBLES studied the projected climate changes (VAN DER Linden, P. and Mitchell, J.F.B.

2009). The regional climate models (RCMs) run at $25 \mathrm{~km}$ spatial resolution for 1951-2100 used the SRES A1B emissions scenario, which estimates the atmospheric carbon-dioxide level to 532 ppm and 717 ppm by 2050 and 2100, respectively (NAKICENOvic, N. and SwART, R. 2000).

The necessary initial and lateral boundary conditions were provided by outputs of global climate models (GCMs). Here we use 9 RCM experiments driven by ECHAM5 (Roeckner, E. et al. 2006) and HadCM3Q (Gordon, C. et al. 2000; Rowell, D.P. 2005) GCMs. These global models were run at the Max Planck Institute in Hamburg Germany, and the Hadley Centre of the UK MetOffice, respectively.

For the analysis of drought conditions in the Carpathian Basin gridded monthly mean temperature values and monthly precipitation amounts of the RCM outputs (Table 6) were used for the end of the $21^{\text {st }}$ century (2071-2100). As a reference period 1961-1990 was selected. 
Table 6. Used regional climate model simulations, their running institutes, and the driving global climate models

\begin{tabular}{l|l|l}
\hline \multicolumn{1}{c|}{ RCM } & \multicolumn{1}{|c}{ Institute, country } & Driving GCM \\
\hline HadRM3Q & METO-HC, United Kingdom & \\
CLM & ETHZ, Switzerland & HadCM3Q \\
RCA3 & C4IR, Ireland & \\
RCA & SMHI, Sweden & \\
\hline RegCM & ICTP, Italy & \\
RACMO2 & KNMI, Netherlands & ECHAM5 \\
REMO & MPI, Germany & \\
HIRHAM & DMI, Denmark & \\
\hline
\end{tabular}

\section{Results}

In order to investigate the future change of the Hungarian drought conditions seasonal mean drought index values have been calculated for the last three decades of the $21^{\text {st }}$ century using the gridded outputs of each RCM, and compared to the reference period. For the spatial analysis the differences are mapped in Figures 1, 2 and 3 using SAI, TAI and PDI, respectively. The four columns represent the different seasons.

The maps in the upper four rows show the results from the RCM simulations driven by HadCM3Q GCM, whereas the lower five rows contain the results from the ECHAM5-driven RCM simulations. Yellow and red colors of the scale indicate drier conditions, while green and blue colors suggest wetter climate. In case of SAI (standardized precipitation index) and TAI (THORNTHWAITE's aridity index) decreasing trends imply drying. Opposite to these indices, increasing PDI (PED's drought index) values indicate drier conditions.

From the maps the drying tendency in summer is clearly seen in using any of the three indices. The other three seasons are also dominated by drying tendencies, however, winter is likely to become wetter according to SAI (Figure 1), which can be explained by the definition of this index, namely, it is based only on precipitation amount, whereas TAI and PDI also consider temperature.

The average seasonal projected changes are summarized in Tables 7, 8 and 9 for Hungary using the grid-cells located within the country. Besides all the individual RCM results, the averages and the standard deviations of the 9-member-ensemble are calculated. The larger projected changes are indicated by italic characters. Since the scales of the three indices are different therefore different thresholds are used: in case of SAI, TAI and PDI large changes are defined as exceeding 0.3, 2.0 and 0.4 in absolute value, respectively. Again note that the signs of the PDI changes are opposite to those of SAI or TAI changes. 


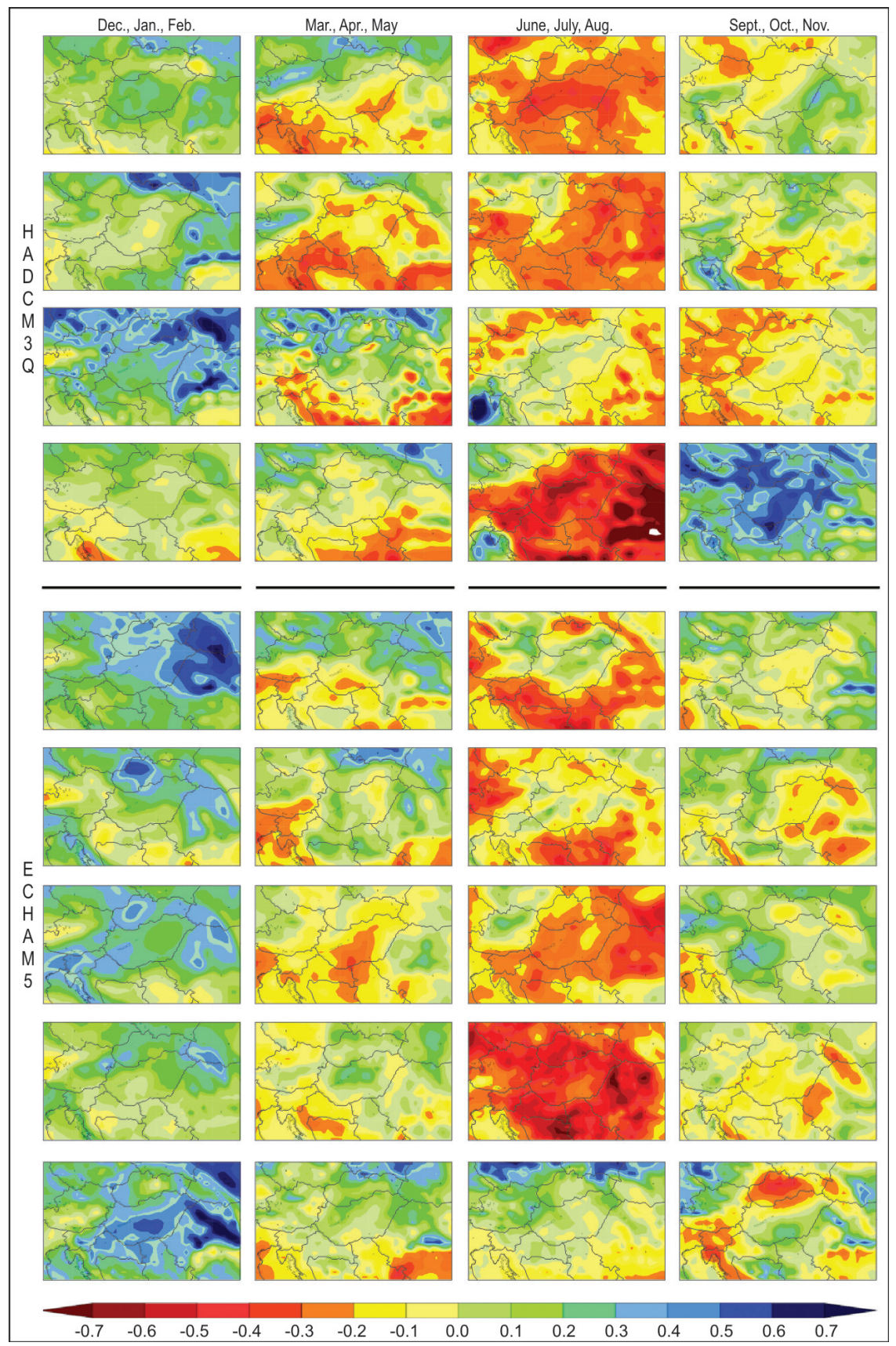

Fig. 1. Projected seasonal changes of SAI by 2071-2100 relative to the 1961-1990 reference period using 9 different RCM simulations 


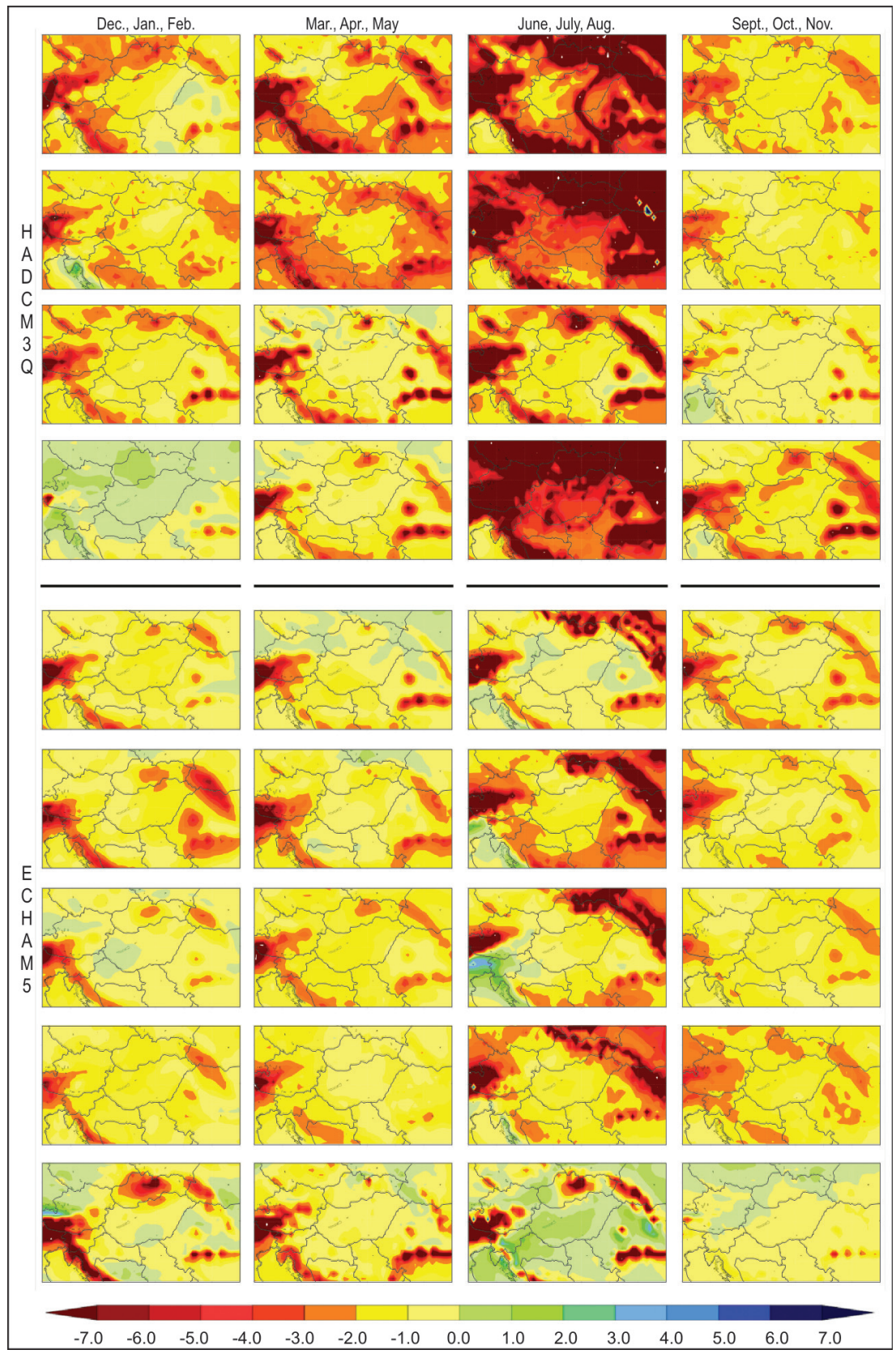

Fig. 2. Projected seasonal changes of TAI by 2071-2100 relative to the 1961-1990 reference period using 9 different RCM simulations 


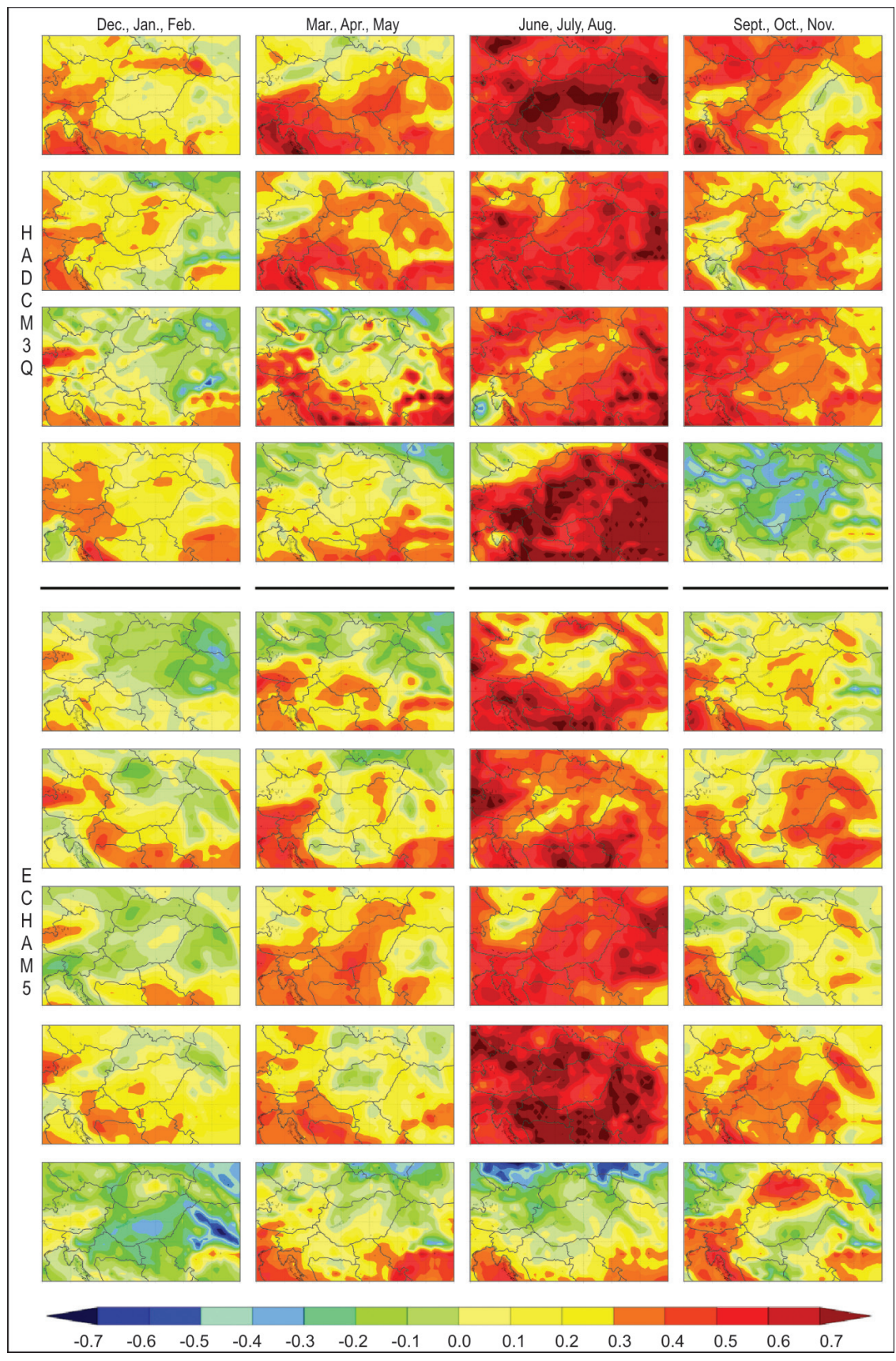

Fig. 3. Projected seasonal changes of PDI by 2071-2100 relative to the 1961-1990 reference period using 9 different RCM simulations 
Table 7. The average projected seasonal changes by 2071-2100 relative to the 1961-1990 reference period for Hungary in case of SAI using 9 different RCM simulations*

\begin{tabular}{l|r|r|r|r|r}
\hline \multicolumn{1}{c|}{ RCM } & DJF & \multicolumn{1}{c|}{ MAM } & JJA & SON & Driving GCM \\
\hline HadRM3Q & 0.21 & -0.10 & -0.37 & 0.05 & \\
CLM & 0.18 & -0.18 & -0.34 & -0.16 & HadCM3Q \\
RCA3 & 0.37 & 0.05 & -0.08 & -0.19 & \\
RCA & 0.19 & -0.09 & -0.50 & 0.39 & \\
\hline RCA & 0.19 & -0.05 & -0.15 & -0.04 & \\
RegCM & 0.22 & 0.09 & -0.07 & -0.18 & \\
RACMO2 & 0.29 & -0.12 & -0.19 & 0.00 & ECHAM5 \\
REMO & 0.18 & 0.02 & -0.48 & -0.15 & \\
HIRHAM & 0.29 & 0.10 & 0.09 & -0.03 & \\
\hline Ensemble-average & 0.24 & -0.03 & -0.23 & -0.03 & \\
Standard deviation & 0.07 & 0.10 & 0.20 & 0.18 & \\
\hline
\end{tabular}

* Changes exceeding 0.3 in absolute value are indicated by italics.

Table 8. The average projected seasonal changes by 2071-2100 relative to the 1961-1990 reference period for Hungary in case of TAI using 9 different RCM simulations*

\begin{tabular}{l|r|r|r|r|r}
\hline \multicolumn{1}{c|}{ RCM } & DJF & MAM & JJA & SON & Driving GCM \\
\hline HadRM3Q & -1.92 & -1.91 & -6.17 & -1.80 & \\
CLM & -1.88 & -2.20 & -11.80 & -1.76 & HadCM3Q \\
RCA3 & -1.64 & -1.66 & -2.18 & -1.11 & \\
RCA & 1.71 & -1.72 & -6.79 & -1.92 & \\
\hline RCA & -0.57 & -1.02 & -1.89 & -1.73 & \\
RegCM & -0.87 & -1.16 & -2.14 & -1.72 & \\
RACMO2 & -0.17 & -1.79 & -1.95 & -1.76 & ECHAM5 \\
REMO & -0.93 & -0.71 & -2.01 & -1.87 & \\
HIRHAM & -0.58 & -1.19 & 0.08 & -0.40 & \\
\hline Ensemble-average & -0.76 & -1.48 & -3.87 & -1.56 & \\
Standard deviation & 1.11 & 0.48 & 3.69 & 0.50 & \\
\hline
\end{tabular}

* Changes exceeding 2.0 in absolute value are indicated by italics.

Table 9. The average projected seasonal changes by 2071-2100 relative to the 1961-1990 reference period for Hungary in case of PDI using 9 different RCM simulations*

\begin{tabular}{l|r|r|r|r|r}
\hline \multicolumn{1}{c|}{ RCM } & DJF & MAM & JJA & SON & Driving GCM \\
\hline HadRM3Q & 0.16 & 0.31 & 0.74 & 0.30 & \\
CLM & 0.10 & 0.32 & 0.63 & 0.28 & HadCM3Q \\
RCA3 & -0.04 & 0.28 & 0.44 & 0.36 & \\
RCA & 0.14 & 0.16 & 0.72 & -0.11 & \\
\hline RCA & -0.13 & 0.14 & 0.38 & 0.19 & \\
RegCM & -0.01 & 0.18 & 0.39 & 0.25 & \\
RACMO2 & -0.14 & 0.23 & 0.48 & 0.19 & ECHAM5 \\
REMO & 0.11 & 0.17 & 0.71 & 0.28 & \\
HIRHAM & -0.19 & 0.12 & 0.01 & 0.23 & \\
\hline Ensemble-average & 0.00 & 0.21 & 0.50 & 0.22 & \\
Standard deviation & 0.13 & 0.08 & 0.23 & 0.13 & \\
\hline
\end{tabular}

* Changes exceeding 4.0 in absolute value are indicated by italics. 
The values suggest that the largest drying in Hungary is projected for summer. Compared to the summer changes less intense drying tendencies are likely to occur in spring and autumn. Winters may result more precipitation in the future (Table 7. - SAI), however, due to the warming trend TAI and PDI suggest overall drier winters in the late $21^{\text {st }}$ century compared to the reference period (Tables 8 and 9, respectively). This can be explained by the increasing evaporation in the warmer environment.

\section{Conclusions}

Precipitation and temperature gridded monthly outputs of 9 RCM simulations (available from the ENSEMBLES project) were used to calculate different type of drought indices (SAI, TAI, PDI) for the Carpathian Basin considering the A1B emissions scenario. Based on the analysis presented in this paper the following conclusions can be drawn:

(i) Summers of the late $21^{\text {st }}$ century are clearly projected to be substantially drier than the 1961-1990 reference period.

(ii) Winter precipitation tends to increase in the future. However, because of the regional warming and the consequent increase of evaporation climatic conditions are projected to become drier in winter, too.

(iii) Springs and autumns tend to become also slightly drier by 20712100 relative to the $1961-1990$ reference period.

The overall drying tendency in the region highlights the necessity to develop the appropriate strategies to adapt to the regional climate change. This is especially important for end-users and decision-makers related to agriculture, food and drinking water security.

Acknowledgements: Research leading to this paper has been supported by the following sources: the Hungarian National Science Research Foundation under grant K-78125, K-83909 and K-109109, the European Union and the European Social Fund joint supports (FuturICT.hu TÁMOP-4.2.2.C-11/1/KONV-2012-0013, GOP-1.1.1.-11-2012-0164, and KMR12-1-2012-0206). The AGRÁRKLÍMA2 project (VKSZ-12-1-2013-0001) and the EEA Grant HU04 Adaptation to Climate Change (EEA-C13-10). The ENSEMBLES data used in this work was funded by the EU FP6 Integrated Project ENSEMBLES (Contract number 505539) whose support is gratefully acknowledged. 


\section{REFERENCES}

Bagrov, N.A. 1983. On the meteorological index of yields. Meteorologiya i Gidrologiya 11. 92-99.

DunKEL, Z. 2009. Brief surveying and discussing of drought indices used in agricultural meteorology. Időjárás 113. 23-37.

Faragó, T., Kozma, E. and Nemes, Cs. 1988. Quantifying droughts. In Identifying and coping with extreme meteorological events. Eds. Antal, E. and Glantz, M., Budapest, Hungarian Meteorological Service, 62-111.

Gordon, C., Cooper, C., Senior, C.A., Banks, H., Gregory, J.M., Johns, T.C., Mitchell, J.F.B. and Wood, R.A. 2000. The simulation of SST, sea ice extents and ocean heat transports in a version of the Hadley Centre coupled model without flux adjustments. Climate Dynamics 16. 147-168.

IPCC, 2012. Managing the Risks of Extreme Events and Disasters to Advance Climate Change Adaptation. A Special Report of Working Groups I and II of the Intergovernmental Panel on Climate Change. Eds. Field, C.B., Barros, V., Stocker, T.F., Dahe, Q., Dokken, D.J., Plattner, G-K., Ebi, K.L., Allen, S.K., Mastandrea, M.D., Tignor, M., Mach, K.J. and Midgley, P.M., Cambridge, UK - New York, USA, Cambridge University Press, $582 \mathrm{p}$.

IPCC, 2013. Summary for Policymakers. In Climate Change 2013: The Physical Science Basis. Contribution of Working Group I to the Fifth Assessment Report of the Intergovernmental Panel on Climate Change. Eds. Stocker, T.F., Qin, D., Plattner, G.-K., Tignor, M., Allen, S.K., Boschung, J., Nauels, A., XiA, Y., Bex, V. and Midglex, P.M., Cambridge, UK - New York, USA, Cambridge University Press, 544 p.

Katz, R.W. and Glantz, M.H. 1986. Anatomy of a rainfall index. Monthly Weather Review 114. 764-777.

Kемг, D. 1990. Global environmental issues: a climatological approach. London-New York, Routledge, $241 \mathrm{p}$.

Nakicenovic, N. and Swart, R. (eds.) 2000. Emissions Scenarios. A Special Report of IPCC Working Group III. Cambridge, UK, Cambridge, University Press, 570 p.

PED, D.A. 1975. On parameters of drought and humidity. Papers of the USSSR Hydrometeorological Center 156. 19-38. (in Russian)

Pongrácz, R., Bartholy, J. and Miklós, E. 2011. Analysis of projected climate change for Hungary using ENSEMBLES simulations. Applied Ecology and Environmental Research 9. 387-398.

Roeckner, E., Brokopf, R., Esch, M., Giorgetta, M., Hagemann, S., Kornblueh, L., Manzini, E., Schlese, U. and Schulzweida, U. 2006. Sensitivity of simulated climate to horizontal and vertical resolution in the ECHAM5 atmosphere model. Journal of Climate 19. 3771-3791.

RoweLL, D.P. 2005. A scenario of European climate change for the late $21^{\text {st }}$ century: seasonal means and inter-annual variability. Climate Dynamics 25. 837-849.

Tallaksen, L.M., Stahl, K. and Wong, G. 2011. Space-time characteristics of large-scale droughts in Europe derived from stream-flow observations and WATCH multi-model simulations. Technical Report No. 48. Oslo, University of Oslo. 16 p.

Thornthwaite, C.W. 1948. An Approach Toward a Rational Classification of Climate. Geography Review 38. 55-94.

van Der Linden P. and Mitchell, J.F.B. 2009. ENSEMBLES: Climate Change and Its Impacts: Summary of research and results from the ENSEMBLES project. Met Office Hadley Centre, UK, $160 \mathrm{p}$. 